\title{
УНІВЕРСАЛЬНА ТВОРЧА ОСОБИСТІСТЬ У МУЗИЧНІЙ КУЛЬТУРІ БУКОВИНИ Й ГАЛИЧИНИ
}

\author{
Коменда О. І., Заєць В. М.
}

\section{ВСТУП}

Розуміння універсалізму творчої особистості, як правило, пов'язане 3 усвідомленням жанрово-стильової багатогранності творчості митця, глибини здійснюваних ним художніх узагальнень, смисловою всеохопністю художніх концепцій, а також винятково високою мірою творчого обдарування. У цьому плані всіх великих музикантів можна 3 повним правом вважати універсалами. Проблематика представленої праці присвячена одному з аспектів універсальної творчої особистості, зокрема діяльнісному універсалізму, що спирається на психологічну теорію О. Леонтьєва і передбачає глибоке та різнобічне вивчення мотиваційно-діяльнісної сфери універсальної творчої особистості.

Спостереження над універсальною творчою особистістю підтверджують, що в різних формах цей феномен трапляється протягом усієї історії людства. Сфокусоване іiї вираження пов'язане 3 культурними здобутками Нового Часу, а власне в музичній культурі найвищу концентрацію прикладів демонструє доба романтизму, 3 iii прагненням до індивідуалізму й фактичним ототожненням творчої особистості та творчої індивідуальності.

Неоціненну роль універсальна творча особистість відіграла в українській культурі, величезний обсяг політичних і культурних завдань якої немовби «,замовляв" діячів універсального типу» (I. Дзюба). Як поет, прозаїк, художник, політичний та громадський діяч проявив себе Т. Шевченко. Як письменник, перекладач, фольклорист, етнограф, мовознавець, критик, культурно-громадський діяч працював П. Куліш. Публіцистом, істориком, філософом, економістом, літературознавцем, фольклористом, громадським діячем та політиком був М. Драгоманов. Письменником, поетом, публіцистом, перекладачем, вченим, громадським діячем, політиком - I. Франко, письменницею, поеткою, перекладачкою, громадською діячкою - Леся Українка. Численні приклади діяльнісного універсалізму особистості можна спостерігати в українській музичній культурі, зокрема в Галичині та на Буковині. Розгляду найхарактерніших представників 
різних типів універсальної творчої особистості вказаних етнографічних регіонів і присвячене це дослідження.

\section{1. Сидір Воробкевич та Анатоль Вахнянин - універсали - громадські діячі}

Сидір Воробкевич i Анатоль Вахнянин - яскраво виражені універсальні особистості, універсали широкого профілю, об'єднані належністю до одного типу - універсал - громадський діяч. Чим зумовлено таке твердження?

Сидір Воробкевич із невичерпною енергією працював як письменник, композитор, диригент, педагог та громадський діяч, 3 юнацьких років писав вірші та малював картини. Він є автором понад чотирьохсот хорових композицій на слова Т. Шевченка, І. Франка, Ю. Федьковича, М. Шашкевича, Я. Головацького, а також власних перекладів німецької поезії, понад сорока романсів та пісень, двадцяти вокальних ансамблів, низки чоловічих квартетів i солоспівів у супроводі чоловічих квартетів, понад тридцяти інструментальних творів - для цитри, гітари, фортепіано.

Найбільше значення для розвитку культури Буковини мали музично-драматичні твори I. Воробкевича (всього 26) - опери, оперети, мелодрами, музичні комедії, пародії. М. Білинська зазначала: «Лірична поезія Д. Млаки без мелодії прямо немислима. Слово й музика зрослися в нього в органічну єдність так міцно, як Млака і Воробкевич: що не договорить Млака, те доспіває Воробкевич» ${ }^{1}$. Сам композитор тексти до своїх пісень вважав тільки половиною роботи, та й то менш важливою й вдалою. I загалом бачив у собі скоріше музиканта, ніж поета. На думку Марії Загайкевич, «С. Воробкевич порушив монополію Liedertafel, створивши вітчизняний замінник» ${ }^{2}$.

Поворотним етапом у житті С. Воробкевича стало повернення до Чернівців й призначення у 1867 . викладачем музики і співів Чернівецької семінарії, де він, окрім проведення занять, ще й керував новоутвореним хором. Педагогічна робота С. Воробкевича з 1869 р. була продовжена на посаді професора музики і співів Чернівецького теологічного інституту, духовної та учительської семінарій, а 3 1875 р. - на посаді професора теологічного факультету Чернівецького університету. Музикант також багато працював із шкільною молоддю (зокрема, в сільських школах в Давидівцях і Руській Молдовиці), що спонукало його укласти «Співаник» для початкової школи

${ }^{1}$ Білинська М. I.I. Воробкевич. Нарис про життя і творчість. Київ : Державне видавництво образотворчого мистецтва і музичної літератури УРСР, 1958. С. 23.

2 Загайкевич М. Творчість Сидора Воробкевича в контексті розвитку української національної культури. Студї мистецтввознавчі. 2016. Ч. 1. С. 67. 
(надрукований трьома випусками ${ }^{3}$ та перші на Буковині українські музично-методичні посібники 3 теорії музики та співу, які відіграли дуже важливу роль у популяризації української народної пісні в міському побуті галицької і буковинської інтелігенції, яка тоді набагато краще знала австрійські liedertafel, ніж рідні народні пісні.

Під керівництвом С. Воробкевича та на його творчості було виховано багато музикантів й діячів мистецтва. Серед них композитор і музикознавець зі світовим ім'ям Євсевій Мандичевський, фольклорист і композитор Порфирій Бажанський, основоположник румунської класичної музики Чіпріян Порумбеску, оперний співак, диригент і композитор Костянтин Шандру та багато інших.

Музикознавча діяльність С. Воробкевича включала різножанрову публіцистику та фольклористичні дослідження. Аналізуючи варіанти народних пісень із різних місцевостей України, С. Воробкевич дійшов висновку про спільне коріння багатьох із них ${ }^{4}$. Музикант часто виступав із лекціями про музику та їі майстрів, публікував науковопопулярні статті в чернівецьких газетах i журналах 5 . Результатом збирання й вивчення буковинських народних пісень ${ }^{6}$ стало опубліковане ним у 1865 р. дослідження «Наша народна пісня».

Диригентська діяльність С. Воробкевича тривала, починаючи від 1860-х і до останніх днів життя. Композитор працював із сільськими хорами, а потім чернівецькими дитячим шкільним, гімназійним i студентським хорами, колективом робітничої молоді i хором чернівецької «Бесіди». Хорова справа здійснила великий вплив на його композиторську творчість. Адже, крім того, композитор часто приносив на репетиції щойно написаний власний твір, перевіряючи на практиці його звучання. У 1870-1880 роках керовані С. Воробкевичем чернівецькі хори набули слави професійних мистецьких колективів. За його почином i участю I. Синкевича, вихованця Перемишльської

3 «Співаник» С. Воробкевича було перевидано в 1893, 1899, 1902, 1905, 1909 та 1910 роках. Білинська М. Сидір Воробкевич. Київ : Музична Україна, 1982. С. 29.

4 Залуцький О. Творчо-мистецька діяльність Сидора Воробкевича у контексті національно-культурного життя Буковини другої половини XIX століття. Краєзнавство. 2013. № 3. С. 159.

5 Статті Д. Млаки були опубліковані також у «Слов'янському альманахові», журналах та довідниках («Буковинсько-Руський Місяцеслов» (Чернівці, 1875-1885 рр.). Білинська М. I. І. Воробкевич. Нарис про життя і творчість. Київ : Державне видавництво образотворчого мистецтва і музичної літератури УРСР, 1958. С. 14.

6 Зібрані С. Воробкевичем на Буковині українські народні пісні при сприянні Я. Головацького увійшли до тритомника українського фольклору, який вийшов у 1878 р. в Москві під назвою «Народные песни Галицкой и Угорской Руси». Але С. Воробкевич не тільки збирав і досліджував народні пісні, але як композитор створював своєрідні хорові в’язанки («кводлібети») з українських народних пісень, такі як «Українська кадриль», «Вінок, сплетений з 36-ти різних квіток». 
школи, в багатьох містах і селах Буковини було організовано хорові гуртки, в яких широко запроваджувався багатоголосний спів замість вживаного до того одноголосного. Таким чином, як довголітній диригент-практик С. Воробкевич відіграв надзвичайно важливу роль у розвитку хорової культури на Буковині.

Важливою була діяльність С. Воробкевича як громадського діяча. У цьому плані його інтереси здавалися неосяжними. У 1870 -х роках він видавав календарі під назвою «Буковинсько-руський місяцеслов», входив до редколегії Чернівецького літературного журналу «Зоря Буковини», редагував слов'янський відділ румунського журналу «Кандела» та буковинський альманах «Руська хата», організував товариство українських студентів, у 1880-1883 роках був головою, а пізніше почесним членом товариства «Руська Бесіда», очолював (з 1884 року) «Руське літературно-драматичне товариство» ${ }^{7}$ в Чернівцях, яке, крім постановок українських п'єс із народного життя, влаштовувало концерти-лекції про театр і музику, а також великі музично-літературні вечори на честь Т. Шевченка, М. Шашкевича, Ю. Федьковича ${ }^{8}$. Концертна діяльність чернівецьких товариств, як $\mathrm{i}$ розвиток усього українського культурного життя на Буковині, нерозривно пов'язана з іменем С. Воробкевича.

Анатоль Вахнянин відомий як письменник ${ }^{9}$, автор публіцистичних творів, проте найцінніший доробок він залишив у галузі музичної культури як композитор, виконавець, громадський діяч, активний учасник хорового руху Західної України, один із засновників Вищого музичного інституту імені М.В. Лисенка у Львові.

Композиторська спадщина А. Вахнянина, крім опери «Купало», включає музику до п’єс «Бондарівна», «Ярополк Перший Святославич», близько сорока хорових творів ${ }^{10}$, обробки народних

7 У 1899 р. на базі «Руського літературно-драматичного товариства» був заснований «Буковинський боян», який ставив за мету «плекати руську пісню, музику і штуку драматичну». Див. : Залуцький О. Творчо-мистецька діяльність Сидора Воробкевича у контексті національно-культурного життя Буковини другої половини XIX століття. Краєзнавство. 2013. № 3. С. 161.

8 Залуцький О. Творчо-мистецька діяльність Сидора Воробкевича у контексті національно-культурного життя Буковини другої половини XIX століття. Краєзнавство. 2013. № 3. С. 161.

9 А. Вахнянин переклав із російської мови українською «Старосвітські дворяни» та «Повість про те, як посварились Іван Іванович 3 Іваном Никифоровичем» М. Гоголя, «Нещасну» I. Тургєнєва, а також створив власні повісті та оповідання «Женщина», «Отець Олександр», збірку Чабарашки на час жнив».

10 Фундаментом хорової музики А. Вахнянина були німецька Liedertafel, поширена у творчості австро-німецьких романтиків та позначена іiї впливами старогалицька пісенність. Див. : Горак Я.Р. Анатоль Вахнянин і становлення музичного професіоналізму в Галичині (друга половина XIX - початок XX ст.) : автореф. дис. ... канд. мистецтвознавства : 17.00.03. Київ. 2003. С. 7-8. 
пісень, кілька солоспівів, найпопулярнішим серед яких виявився «Помарніла наша доля». Найвищим ж досягненням композиторської творчості А. Вахнянина стала опера «Купало», робота над якою тривала від 1870 і до 1892 року і яка, на думку Р. Горака, за своїми жанрово-інтонаційними особливостями виявилася найбільш співзвучною ранньоромантичній німецькій опері (К.М. Вебер) ${ }^{11}$. Сам композитор був дуже скромної думки про свою творчість: «Твори свої я писав принагідно, без всяких претензій, бо я ж автодидакт (самоук) на полі музики» ${ }^{12}$.

Доповненням багатогранної діяльності А. Вахнянина стали його педагогічна праця та виконавство. Закінчивши в 1863 році семінарію, А. Вахнянин протягом трьох років працював на посаді вчителя української мови в Перемишльській гімназії, де створив учнівське товариство «Громада», а при ньому - гурток співу. У 1868 році після закінчення історико-географічного факультету Віденського університету він перейшов на посаду вчителя гімназії у Львові. У 1889 році уклав та опублікував «Співаник для середніх шкіл».

Діяльність А. Вахнянина як хорового диригента була пов'язана із співочим товариством «Львівський Боян», першим диригентом якого його було обрано у 1891 році. Іларіон Гриневецький писав із цього приводу про виконання «Заповіту» М. Вербицького, «Іван Гуса» М. Лисенка, «Молитви» 3 опери «Купало» А. Вахнянина в Стрию, Станіславі, Лавочнім, Кракові й Празі. Нерідко виступав і як співак, виконавець власних творів ${ }^{13}$.

А. Вахнянин - автор рецензій на театральні постановки («Запорожця за Дунаєм» С. Гулака-Артемовського, «Різдвяної ночі» М. Лисенка та ін.), книги («Руський співаник і малий катехізм музики, зложений Матюком», працю П. Демуцького «Ліра та ії мотиви» та ін.), низки публіцистичних дописів і наукових статей («Дещо про значення пісень народних у слов'ян, іменно у русинів» та ін.) $)^{14}$, а також підручника «Наука гармонії», написаного для потреб Вищого музичного інституту.

Найвизначнішу сторінку діяльності А. Вахнянина становить рідкісно масштабна музично-громадська діяльність. Він був першим

11 Горак Я.Р. Анатоль Вахнянин і становлення музичного професіоналізму в Галичині (друга половина XIX - початок XX ст.) : автореф. дис. ... канд. мистецтвознавства : 17.00.03. Київ. 2003. С. 11.

${ }^{12}$ Гриневецький І. А.К. Вахнянин. Нарис про життя і творчість. Київ : Державне видавництво образотворчого мистецтва і музичної літератури УРСР, 1961. С. 31.

${ }^{13}$ Там само. С. $10-13$.

14 Горак Я.Р. Анатоль Вахнянин і становлення музичного професіоналізму в Галичині (друга половина XIX - початок XX ст.) : автореф. дис. ... канд. мистецтвознав. : 17.00.03. Київ. 2003. С. 8-10. 
головою українського студентського товариства «Січ», заснованого у 1868 році у Відні. Цього ж року, повернувшись до Львова, долучився до створення товариства «Просвіта» і був обраний першим його головою (1868-1870 pp. $)^{15}$.

У 1870 році А. Вахнянин заснував у Львові співоче товариство «Торбан», у 1881 році - «Руське Педагогічне Товариство», у 1891 році разом з Володимиром Шухевичем - співоче товариство «Львівський Боян», вів дуже активну видавничу діяльність, працював у різноманітних комісіях - із впорядкування підручників, в «Артистичній комісії», був заступником голови правління польського товариства «Лютня», брав участь у становленні Наукового товариства імені Т. Шевченка (директор історико-філософської секції), був депутатом віденського парламенту та галицького сейму (1894-1900), засновником Вищого музичного інституту імені М.В. Лисенка у Львові (1904), музичні філії якого були організовані в різних містах Галичини. Розуміючи значення цього навчального закладу та заслуг А. Вахнянина в його організації, загальні збори Музичного товариства імені М.В. Лисенка, що відбулися 17 листопада 1907 р., обрали його своїм почесним членом.

\section{2. Василь Барвінський - класичний універсал}

Василь Барвінський увійшов в українську музичну культуру композитором, піаністом, педагогом, музикознавцем, музичногромадським діячем, керівником Вищого музичного інституту імені М.В. Лисенка у Львові, що понад тридцять років «стояв на чолі музичного життя міста» ${ }^{16}$.

Композиторська творчість В. Барвінського - оригінальна, різножанрова i досить численна. Значна іiі частина була цинічно знищена радянською владою у 1948 році (фортепіанні Варіації на власну тему, Варіації на тему української колядки, Концерт для фортепіано з оркестром f-moll та інші), коли композитора було заслано на десять років до Сибіру, і після повернення В. Барвінського до Львова відновлена лише частково.

В. Барвінський - передусім, майстер камерного жанру, автор камерно-інструментальних та камерно-вокальних композицій. Серед відомих фортепіанних творів - мініатюри «Жаб'ячий вальс», «Прелюдія методою Ж. Далькроза» та «Листок до альбому», цикл прелюдій, соната,

15 Кінд-Войтюк Н. Анатолій Вахнянин - голова товариства «Просвіта». Науковий вісник Східноєвропейського національного університету імені Лесі Украӥнки. 2016. Вип. 3. С. 80.

16 Барвінський В. Статті та матеріали / упоряд. В. Грабовський. Дрогобич : Відродження, 2000. С. 4. 
«Українська сюїта» та інші. До визначних досягнень В. Барвінського належить фортепіанний секстет c-moll (для двох скрипок, альта, віолончелі, контрабаса і фортепіано), написаний у Празі в 19141915 роках. У середині $1930-\mathrm{x}$ років композитор написав цінну педагогічну збірку «Наше сонечко грає на фортепіано» - 20 дитячих п’єс для фортепіано на українські народні мелодії для учнів молодших класів.

Творчість В. Барвінського виявляє його ліричне обдарування. Вона співзвучна модерним стильовим тенденціям, зокрема, виразними в ній $\epsilon$ риси імпресіонізму, прикладом чого можуть бути прелюдії, соната та багато інших творів для різних виконавських складів.

Важливою гранню творчої самореалізації В. Барвінського було фортепіанне виконавство. Він багато працював над собою як піаніст, виступав соло та в ансамблях, виконував власні фортепіанні твори Прелюдії, мініатюри, фортепіанний цикл «Любов», «Українську сюїту», Серенаду. 3 преси відомо про виступи В. Барвінського 1918, 1920 років, зокрема, про те, що він виступав із багатьма відомими співаками М. Менцінським, Р. Любінецьким, М. Голинським, О. Носалевичем, А. Крушельницькою, О. Любич-Парахоняк, М. Маслюком ${ }^{17}$.

Iз власних фортепіанних творів В. Барвінський виконував також фортепіанне тріо a-moll (№2), зокрема, у 1918 році - разом 3 артистами Перфецьким і Богданом Бережницьким (віолончель), а також тpio es-moll (№ 1) - у 1926 році. Обидва виконання здійснено у Львові. 3 Б. Бережницьким В. Барвінський постійно виступав протягом 19241929 років $^{18}$. У 1928 році В. Барвінський провів серію концертів із М. Менцінським - у Львові, Бориславі, Самборі, Дрогобичі, Стрию та Яворові.

Важливу роль у структурі творчої особистості В. Барвінського посідає його музикознавча діяльність. Він активно виступав як кореспондент львівських газет, автор кількох сотень рецензій, які писав протягом більш, ніж півстоліття, аналітичних статей, передач на радіо, численних рефератів про визначних діячів української та європейської культури (лише про Лисенка - понад десяток) $)^{19}$. Із 1915 до 1948 року В. Барвінський постійно друкувався у спеціальних виданнях

17 Тихонюк Б.М. Концертно-освітня діяльність Василя Барвінського за оцінкою львівської преси 20-х років. Українське музикознавство. 1990. Вип. 25. С. 79-81.

18 У 1928 році відбулася низка успішних концертів В. Барвінського і Б. Бережницького на Наддніпрянській Україні, зокрема в Києві, Харкові, Дніпропетровську та Одесі. Див. : Тихонюк Б.М. Концертно-освітня діяльність Василя Барвінського за оцінкою львівської преси $20-\mathrm{x}$ років. Українське музикознавство. 1990. Вип. 25. С. 81-85.

19 Грабовський В. Музикознавчі дослідження та публіцистика Василя Барвінського. Барвінський В. 3 музично-письменницької спадщиини. Дослідження, публічистика, листи / упоряд. В. Грабовський. Дрогобич : Коло, 2004. С. 3-9. 
«Мистецтво», «Новий час», «Життя», «Наша культура», «Українська музика», а також польській і чеській періодиці ${ }^{20}$.

Музикознавчі праці В. Барвінського включають біографічні нариси та популярні статті («Мої спомини про Лисенка», «Віктор Косенко», «Митець великого обдарування (про С. Людкевича)», «Бела Барток у Львові», «Творчість В. Новака»), статті, присвячені фольклорній тематиці («Українська народна пісня і українські композитори», «Характеристика української народної пісні та іiї дослідження»), дослідження 3 історії української музичної культури («Українська музика (нова доба)» у співавторстві з Ф. Стешком, С. Людкевичем, жанр «3 історії української музичної культури Західної України»).

Педагогічна діяльність - ще одна важлива сторінка творчості В. Барвінського. Починаючи 31915 року, він викладав гармонію та фортепіано у Вищому музичному інституті імені М. Лисенка, понад тридцять років перебуваючи на чолі цього навчального закладу. Серед вихованців В. Барвінського - композитори 3. Лисько, М. Колесса, А. Рудницький, піаністи Д. Гординська-Каранович, Р. Савицький, С. Сапрун-молодший, Р. Сімович, І. Любчак-Крихова, І. Негребецька, Б. Пюрко, Л. Мечник-Чепага, О. Криштальський та інші. Педагогічна праця В. Барвінського мала великий вплив на розвиток музичної культури Галичини, адже він «зумів увібрати і органічно сплавити в одному стилі найцінніший спадок різноманітних львівських піаністичних традицій» ${ }^{21}$.

Інтенсивною була громадська діяльність митця. Разом із С. Людкевичем до початку Другої світової війни створював філії Вищого музичного інституту у Дрогобичі, Перемишлі, Станіславі, Тернополі, Яворові, Бориславі, Коломиї, Золочеві, Самборі, Рогатині. У 1934-1936 роках керував композиторською секцією Союзу українських професійних музик, у 1936-1938 роках був головою цієї організації, вів активну музично-громадську діяльність як ректор Вищого музичного інституту імені М. Лисенка, пізніше - директор Львівської консерваторії та голова Львівського відділення Спілки композиторів.

Важливою була роль В. Барвінського у створенні в 1937 році спеціального журналу «Українська музика», до складу редколегії якого він входив у 1937-1939 роках.

${ }^{20}$ Соловей Л. Деякі аспекти діяльності В. Барвінського та його учнів 3. Лиська, Р. Савицького. Барвінський В. Статті та матеріали / упоряд В. Грабовський. Дрогобич : Відродження, 2000. С. 62.

${ }^{21}$ Карась Г. Музична культура української діаспори у світовому часопросторі XX століття. Івано-Франківськ : Тіповіт. 2012. С. 402. 
Всі види творчої діяльності В. Барвінського були тісно переплетені між собою. Концертуючий піаніст (соліст, ансамбліст, концертмейстер), він сам виконував більшість своїх творів, особливу увагу приділяв фортепіанному, камерно-інструментальному та камерно-вокальному жанрам композиторської творчості. Багаторічний успішний педагог написав чимало творів педагогічного призначення. Один із найактивніших організаторів музичного життя краю - тривалий час очолював Вищий музичний інститут імені М.В. Лисенка. Як музичний критик В. Барвінський значну увагу приділяв фортепіанному виконавству. Як педагог, виховував і піаністів, і композиторів, і музикознавців, багато 3 яких надалі виявилися універсальними особистостями (З. Лисько, Р. Савицький та інші). Лірична природа обдарування В. Барвінського проявлялася i в композиторському мисленні, i в особливостях виконавської манери та музикознавчого письма. Українська основа композиторської творчості перегукувалася 3 наскрізною українською тематикою i проблематикою музикознавчих зацікавлень. Громадська активність у проекції на його музикознавчі інтереси зумовила заняття В. Барвінського редакторською діяльністю в журналі «Музика», в якому він, окрім іншого, мав змогу публікувати і власні праці. Таким чином, 3 огляду на синтетичний характер творчих досягнень В.Барвінського, можна стверджувати, що в його особі західноукраїнська музика отримала яскравий приклад класичного універсала.

\section{3. Микола Колесса і Василь Витвицький - універсал-виконавець та універсал-музикознавець}

Микола Колесса поєднав багатогранну композиторську творчість, натхненну практику диригента, педагога, мистецтвознавця і активного громадського діяча. Автор двох симфоній, сюїти, варіацій для симфонічного оркестру, сюїти для струнного оркестру, багатьох камерних, вокальних творів. М. Колесса залишив нащадкам різноманітну творчу спадщину. Творам міжвоєнного двадцятиліття притаманні прояви конструктивізму, неофольклоризму, неокласицизму (вокальні композиції, Варіації для симфонічного оркестру, фортепіанні та струнні сюїти, сонатина для фортепіано) ${ }^{22}$, композиціям 1950-1960-х років - риси соцреалізму (триптих для хору і симфонічного оркестру, друга симфонія).

22 Стельмащук Р. Композитор Микола Колесса та львівський музичний «модернізм» міжвоєнного двадцятиріччя. Родина Колессів у духовному та культурному житті України кінця XIX-XX століття. Вип. 5. Львів, 2005. C. 303-311. 
Творчість М. Колесси, «хоч не надто численна кількісно, є вельми вартісною в художньому відношенні, але часто недооцінюваною сучасниками» ${ }^{23}$. Сам композитор скромно висловлювався про свої творчі можливості: «Я не маю себе за якогось дуже великого мистця, 3 якого творча інтенція „б’є фонтаном”, проте в рамках відпущених мені здібностей і таланту старався нічого не занедбати і не поминути» ${ }^{24}$.

Великий внесок в українську музичну культуру здійснив Микола Колесса як диригент. Він був одним із засновників симфонічного оркестру Львівської філармонії, художнім керівником хорової капели «Трембіта», диригентом Львівського театру опери та балету. Л. Кияновська зазначає: «Загалом, якщо б тільки перерахувати, скількома хорами впродовж своєї тривалої диригентської кар'єри керував Микола Філаретович, то вийшло б щонайменше десять колективів, а може навіть і більше: «Станіславівський Боян», «Львівський Боян», «Бандурист», «Студіо-хор», дитячий хор ВМI ім. М. Лисенка, «Думка» в Станіславові, «Стрийський Боян», вже після війни - “Трембіта”»". Діяльність М. Колесси як диригента була дуже інтенсивною, він виступав у Києві, Харкові, Одесі, Москві i, крім класичного репертуару, дав життя кільком десяткам партитур С. Людкевича, В. Барвінського, Р. Сімовича та А. Кос-Анатольського.

М. Колесса пригадував: «Диригувати я дуже любив. До сьогоднішнього дня вважаю великою своєю помилкою, що в 50-ті роки покинув посаду диригента у філармонії і став ректором консерваторії». Любов Кияновська зауважує: «Може видатись дещо дивним, що, стільки років пропрацювавши 3 хоровими колективами, зростаючи на традиціях хорового співу і в родині, і в ширшому оточенні галицької інтелігенції, Микола Філаретович, все-таки, понад усе любив диригувати оркестром. Коли ми заговорили про його діяльність диригента симфонічного оркестру - о! як загорілись в нього очі, як жваво, по-молодечому зазвучав його голос, і в розмові з'явились ті ліричні нотки, якими були сповнені розповіді хіба що про перше кохання чи деякі найдорожчі празькі епізоди: „Так, направду, найбільше в своєму житті я любив диригувати оркестром. Я за це навіть поплатився здоров'ям, бо ось, погляньте, - витягнув він вперед праву руку, - моя рука тепер постійно болить, через багаторічне диригування я вже постійно буду ії відчувати. Але ні про що не жалію,

${ }^{23}$ Кияновська Л. Син століття. Микола Колесса в українській культурі ХХ віку. Львів : Видавництво НТШ. 2003. С. 12.

${ }^{24}$ Там само. С. 242.

${ }^{25}$ Там само. С. 196. 
бо стояти перед оркестром - це ні 3 чим не порівняне відчуття. Для мене це була така велика радість"» ${ }^{26}$.

Як педагог М. Колесса $є$ фундатором львівської диригентської школи. Він виховав цілу плеяду диригентів провідних мистецьких колективів України, серед яких - Степан Турчак, Юрій Луців, Іван Гамкало, Руслан Дорожівський, Роман Филипчук, Іван Юзюк, Тарас Микитка, Ярема Скибінський, Богдан Антків, Володимир Василевич, Свген Вахняк, Михайло Антків, Ярема Колесса, Богдан Герявенко та інші.

Педагогічна діяльність М. Колесси протікала у Вищому музичному інституті імені М.В. Лисенка (1931-1939) та Львівській консерваторії (1953-1965, ректор; 1965-1974 - завідувач кафедри диригування; 3 1974 р. - професор-консультант). Серйозність ставлення М. Колесси до навчального процесу підтверджує його навчально-методична робота («Порадник диригента», «Основи техніки диригування»).

Потужну виконавську, педагогічну та композиторську творчість М. Колесси доповнює його громадська та музично-критична діяльність. Він - багаторічний член Правління Спілки композиторів СРСР та Спілки композиторів України, багато уваги приділяє роботі львівського відділення товариства «Україна» та Львівського відділення Товариства радянсько-чехословацької дружби, головою якого був понад два десятиліття. Як музичний критик виступає в пресі з рецензіями на концерти Т. Микиші, А. Люфера, Л. Сагалова ${ }^{27}$.

Універсальна творча особистість М. Колесси належить до типу універсала-виконавця, на що вказує домінування диригентської праці над усіма іншими. Саме вона визначає важливі акценти в інших видах творчої активності митця. Хорові і симфонічні твори в композиторській спадщині бачаться результатом захоплення М. Колессою диригуванням (відображення досвіду диригента у фактурі). Натомість активність першовиконань творів українських композиторів свідчить про вплив на його диригентську практику композиторського амплуа. За словами М. Колесси, диригування було його найулюбленішою справою. Диригування визначало характер педагогічних досягнень (працював не на кафедрі композиції, а на кафедрі диригування ${ }^{28}$ ) та зміст навчальнометодичних праць.

${ }^{26}$ Кияновська Л. Син століття. Микола Колесса в українській культурі ХХ віку. Львів : Видавництво НТШ. 2003. С. 197.

${ }^{27}$ Паламарчук О. Микола Колесса. Київ : Музична Україна, 1989. С. 25.

${ }_{28}$ М. Колесса зауважував: «Взагалі так склалося, що учнів 3 композиції я не мав - остерігався, не зважувався, а $з$ диригування завжди працював 3 молоддю 3 величезною приємністю» Див. : Кияновська Л. Син століття. Микола Колесса в українській культурі ХХ віку. Львів : Видавництво НТШ. 2003. С. 227-228. 
Василь Витвицький - музикознавець, педагог, диригент, композитор, громадський діяч, член Наукового товариства імені Т. Шевченка, один із фундаторів його Музикологічної комісії, випускник Ягеллонського університету за спеціальністю «музикознавство». Постать В. Витвицького є малодослідженою, проте навіть ті відомості, які існують, демонструють органічний універсалізм його творчої особистості, провідну роль у структурі якої виконує музикознавство.

Найгрунтовнішим дослідженням В. Витвицького стала його докторська праця, яку він захистив у Кракові у 1932 році, і яка була присвячена історії української галицької пісні другої половини XIX століття. 3 переїздом до Львова у 1937 році В. Витвицький активно виступав у пресі як музичний критик та публіцист - із дописами про шевченківські вечори, створення української філармонії, коментуванням програм львівського радіо. Його перу належать наукові розвідки «Українські впливи у Шопена» (1934), «Музичне життя Карпатської України» (1939), «Взаємини М. Лисенка 3 І. Франком» (1942), «Стрілецька пісня» (1944), спільно з М. Колессою та З. Лиськом В. Витвицький підготував і опублікував «Диригентський порадник» (1938). Пізніше, перебуваючи в еміграції, він брав участь у написанні «Енциклопедії українознавства», з 1949 року, мешкаючи в США, публікувався в часописах «Новий шлях», «Нові дні», «Свобода», редагував збірник на пошану Григорія Китастого ${ }^{29}$. Музикознавча спадщина В. Витвицького становить майже 250 праць різних жанрів, у т. ч. оглядів, рецензій, присвячених винятково українській музиці, та включає монографії про М. Березовського й М. Гайворонського.

Педагогічною працею В. Витвицький займався протягом усього життя. Її початок був пов'язаний вз Перемишлем, де він у 19291937 роках викладав музично-теоретичні дисципліни, а невдовзі і був директором філії Вищого музичного інституту імені М.В.Лисенка. У львівський період, до 1944 року, В. Витвицький викладав у Львівській консерваторії, а, мешкаючи з 1949 року в США, викладав в Українському музичному інституті у Детройті ${ }^{30}$. Диригентська діяльність В. Витвицького розпочалася ще під час його навчання у Кракові, де він керував хором українських студентів, а пізніше була продовжена у 1929-37 роках в Перемишлі, де він диригував «Перемишльським Бояном», виконуючи твори С. Людкевича,

${ }^{29}$ Ясіновський Ю. Василь Витвицький. Науковий вісник Національної музичної академії України імені П.І. Чайковського. 2002. Вип. 16. Культурологічні проблеми української музики (наукові дискурси пам'яті академіка І. Ф. Ляшенка). С. 273.

${ }^{30}$ Там само. C. 271. 
В. Барвінського та інших українських композиторів ${ }^{31}$. Як композитор В. Витвицький - автор фортепіанного тріо, струнного квартету, низки п’єс для фортепіано, «Пісні і танцю» для камерного оркестру.

Значною була громадська діяльність В. Витвицького. Більша іiі частина належить до українського, німецького та американського періодів. Мешкаючи у Львові, В. Витвицький брав безпосередню участь у влаштуванні урочистостей із нагоди 100-річчя 3 дня народження М. Лисенка (1942), працював в Українському видавництві, видаючи твори С. Людкевича, 3. Лиська, Н. Нижанківського. Виїхавши на Захід, брав участь у з’їзді Мистецького Українського Руху (МУР), що проходив у 1946 році в Авсбурзі ${ }^{32}$. Разом із Нестором Городовенком, Зиновієм Лиськом, Романом Савицьким, Андрієм Ольховським проводив установчі збори Об'єднання Українських Музик (ОУМ) у Карлсфільді під Мюнхеном, на яких його було обрано головою спілки, що активізувала життя українців Німеччини. Iз 1949 року, проживаючи в США, В. Витвицький працював в українській редакції радіо, організовував численні конкурси і фестивалі, видання творів українських композиторів.

\section{ВИСНОВКИ}

Універсальна творча особистість посіла значне місце у формуванні професійної музичної культури Галичини та Буковини. Ї̈̈ роль виявилася особливо важливою на етапах заснування та структурування музичної культури, пізніше - у посиленні потенціалу в періоди інтенсивного розвитку, збереженні основ і підтримці в кризові моменти. Аналіз специфіки універсальної творчої особистості Галичини та Буковини в контексті відповідних історичних процесів продемонстрував, що саме тип універсала - громадського діяча виявився в ній найбільш затребуваним, крім того громадська діяльність посіла вагоме місце і в структурах універсальної творчої особистості ряду музикантів інших типів.

Початки формування музичної культури Буковини та Галичини виявили гостру потребу в типові універсала - громадського діяча. Таку роль виконали Сидір Воробкевич та Анатоль Вахнянин, і в цьому плані їхні функції можна порівняти з функціями М. Лисенка, К. Стеценка та Я. Степового в Наддніпрянській Україні. Значну увагу приділив громадській діяльності універсал-виконавець (диригент), композитор,

31 Там само.

32 Ясіновський Ю. Василь Витвицький. Науковий вісник Наџіональної музичної академії України імені П. І. Чайковського. 2002. Вип. 16. Культурологічні проблеми української музики (наукові дискурси пам'яті академіка І. Ф. Ляшенка). С. 272-273. 
педагог та музикознавець Микола Колесса, значення якого в музичній культурі Галичини можна співвіднести зі значенням Олександра Кошиця в музичній культурі Наддніпрянської України. Левову частку питань розвитку i утвердження галицької музичної культури міжвоєнного періоду довелося вирішувати класичному універсалу Василю Барвінському (композитор, піаніст, педагог, музичногромадський діяч, музикознавець), певним аналогом діяльності якого можна назвати здобутки П. Козицького та М. Вериківського в Наддніпрянській Україні. Універсал-музикознавець Василь Витвицький дзеркально «повторив» ситуацію Б. Яворського та М. Рославця, оскільки більша частина його життя і творчості пройшла за межами України - в Польщі, Німеччині та США.

\section{АНОТАЦІЯ}

Запропоноване дослідження присвячене універсальній творчій особистості Галичини та Буковини, розглянутій в аспекті діяльнісного універсалізму. На прикладі кількох найяскравіших музикантівуніверсалів, представників вказаних регіонів (С. Воробкевич, А. Вахнянин, В. Барвінський, М. Колесса, В. Витвицький) розглянуто основні тенденції розвитку універсальної творчої особистості, визначено та охарактеризовано iї основні типологічні функції у формуванні регіональної музичної культури та національної культури загалом. Зокрема, розкрито функціональну відповідність типу універсала - громадського діяча (С. Воробкевич, А. Вахнянин) та функціональну невідповідність типу універсала-музикознавця (В. Витвицький) завданням розбудови регіональної музичної культури того часу. Визначено роль класичного універсалізму в галицькій музичній культурі радянського періоду (В. Барвінський) як способу протистояти знищенню національної музичної традиції. Доведено високий культуротворчий потенціал універсальної творчої особистості в процесах формування і розвитку музичної культури Галичини та Буковини, а також значущість типу універсала - громадського діяча як характерного явища регіональної та національної музичної культури того часу. Висвітлено та обгрунтовано вагоме значення музичногромадської діяльності для особистостей універсалів інших типів (М. Колесса, В. Витвицький). Зазначено, що виявлені тенденції проявів універсальної творчої особистості Галичини та Буковини загалом суголосні діяльності музикантів-універсалів Наддніпрянської України.

\section{SUMMARY}

The proposed research is the first study in the Ukrainian musicology of the phenomenon of the Universal Creative Personality in musical culture of 
Galicia and Bukovyna. The author considered this phenomenon in the individual-creative, comparative-typological and functional-dynamic aspects. The focus and methodology of the research give an opportunity to understand the specifics of the universal creative individual. This allows scientists to understand the phenomenon of creative individuality. The proposed new ways make it possible to comprehend the format of the Ukrainian musical culture and the meanings of the world musical-historical process deeper and more accurately.

In the study the functional specificity of typological manifestations of the activity universalism is demonstrated on the material of the Ukrainian musical culture of the second half of the $19^{\text {th }}$ and $20^{\text {st }}$ centuries, in particular, universal musicians of Galicia and Bukovyna. The essence of the of the universal creative personality of the New Time phenomenon is clarified through the a complex of types of universal musicians of the New Time developed by O. Komenda. She also substantiated the activity-structural method of research of typological manifestations of universal creative personality.

In this paper the development of universal creative personality is considered on example of several brightest musicians-universals from Galicia and Bukovyna. S. Vorobkevych, A. Vakhnianyn, V. Barvinsky, M. Kolessa, V. Vytvytsky as a creative personalities are representating the phenomenon of universal musicions of their regions. Author characterized the basic typological functions of universal creative personality in regional music culture and national culture in general. In particular, scientist described the functional correspondence of the type of universal-public figure (S. Vorobkevych, A. Vakhnianyn) and the functional inconsistency of the type of universal-musicologist (V. Vytvytsky) to the developing tasks of regional musical culture in XIX and XX centuries. Researcher determined the role of classical universalism in the Galician musical culture of the Soviet period (V. Barvinsky) as a way to resist the destruction of the national musical tradition. O. Komenda proved the high cultural potential of the universal creative personality in the processes of development of Galicia and Bukovyna musical culture. She demonstrated the significance of the universal public figure type as a characteristic phenomenon of regional and national musical culture and highlighted the important significance of public activity for universals of other types (M. Kolessa, V. Vytvytsky). O. Komenda noted that the revealed tendencies of the universal creative personality in the Galicia and Bukovyna music culture in general are in agreement with the activities of universal musicians of Dnieper Ukraine.

In this research a series of scientific approaches has been further developed, in particular: the cultural-historical theory of L. Vygotsky and his conception of interiorization, the O. Leontiev's theory of activity personality, the V.Stern's concept of the psychological type, the N. Herasymova- 
Persydska's concept of the type of musician, the O. Zinkewycz's concept of the music-historical process, the M. Druskin's ideas about a personality as a reflection of the typological norm of his time, the N. Savytska's ideas of a dynamic study of the creative personality, the I. Drach's ideas of internalexternal determination of personality, the L. Shapovalova's ideas of the reflexive personality, the V. Zharkova's ideas of considering the creative "I" in various contextual dimensions, the V. Redya's ideas of integrity and integrative thinking, the Y. Chekan's ideas of the intonational image of the world as the localization of the author's point of view.

The author specifies such concepts: the phenomenon of activity universalism, universal creative personality, leading and auxiliary activities, the structure of activity universalism, the functions of a universal creative personality and types of activity universalism in the music-historical process, the role of activity universalism in the Ukrainian national musical culture.

\section{ЛIТЕРАТУРА}

1. Барвінський В. Статті та матеріали / упоряд. В. Грабовський. Дрогобич : Відродження, 2000. 148 с.

2. Білинська М. І.І. Воробкевич. Нарис про життя і творчість. Київ : Державне видавництво образотворчого мистецтва i музичної літератури УРСР, 1958. $50 \mathrm{c}$.

3. Білинська М. Сидір Воробкевич. Київ : Музична Україна, 1982. 45 с.

4. Горак Я.Р. Анатоль Вахнянин i становлення музичного професіоналізму в Галичині (друга половина XIX - початок XX ст.) : автореф. дис. ... канд. мистецтвознавства: 17.00.03. Київ. 2003. 17 с.

5. Грабовський В. Музикознавчі дослідження та публіцистика Василя Барвінського. Барвінський $B .3$ музично-письменницької спадщини. Дослідження, публіцистика, листи / упоряд. В. Грабовський. Дрогобич : Коло, 2004. С. 3-9.

6. Гриневецький I. А.К. Вахнянин. Нарис про життя і творчість. Київ: Державне видавництво образотворчого мистецтва і музичної літератури УРСР, 1961. $31 \mathrm{c}$.

7. Загайкевич М. Творчість Сидора Воробкевича в контексті розвитку української національної культури. Студії мистецттвознавчі. 2016. Ч. 1. С. 62-69.

8. Залуцький О. Творчо-мистецька діяльність Сидора Воробкевича у контексті національно-культурного життя Буковини другої половини ХІХ століття. Краєзнавство. 2013. № 3. С. 158-164.

9. Карась Г. Музична культура української діаспори у світовому часопросторі XX століття. Івано-Франківськ : Тіповіт. 2012. 1164 с.

10. Кияновська Л. Син століття. Микола Колесса в українській культурі ХХ віку. Львів : Видавництво НТШ. 2003. 291 с. 
11. Кінд-Войтюк Н. Анатолій Вахнянин - голова товариства «Просвіта». Науковий вісник Східноєвропейського національного університету імені Лесі Украӥнки. 2016. Вип. 3. С. 79-82.

12. Паламарчук О. Микола Колесса. Київ : Музична Україна, 1989. 76 с.

13. Соловей Л. Деякі аспекти діяльності В. Барвінського та його учнів 3. Лиська, Р. Савицького. Барвінський В. Статті та матеріали / упоряд. В. Грабовський. Дрогобич : Відродження, 2000. С. 59-66.

14. Стельмащук Р. Композитор Микола Колесса та львівський музичний «модернізм» міжвоєнного двадцятиріччя. Родина Колессів у духовному та культурному житті Украйни кіния XIX-XX століття. 2005. Вип. 5. С. 303-311.

15. Тихонюк Б.М. Концертно-освітня діяльність Василя Барвінського за оцінкою львівської преси 20-х років. Украӥнське музикознавство. 1990. Вип. 25. С. 79-86.

16. Ясіновський Ю. Василь Витвицький. Науковий вісник Наиіональної музичної академії України імені П.І. Чайковського. 2002. Вип. 16. Культурологічні проблеми української музики (наукові дискурси пам’яті академіка І.Ф. Ляшенка). С. 271-273.

Information about the authors: Komenda O. I., Doctor of Art History, Associate Professor at the Department of History, Theory of Arts and Performance Lesya Ukrainka Volyn National University 15, Kovelskaya str., Lutsk, Ukraine

Zaets V. M., Candidate of Art Criticism, Associate Professor, National Music Academy of Ukraine named after P. I. Tchaikovsky 1/3-11, Architector Gorodetsky str., Kyiv, 01001, Ukraine 